\title{
SLUG CONTROL IN LEAFY VEGETABLE USING NEMATODE PHASMARHABDITIS HERMAPHRODITA (SCHNEIDER)
}

\author{
GRUBIŠIĆ, D. ${ }^{1 *}$ - GOTLIN ČULJAK, T. ${ }^{1}$ - MEŠIĆ, A. ${ }^{1}$ - JURAN, I. ${ }^{1}$ - LOPARIĆ, A. ${ }^{1}$ - \\ STARČEVIĆ, D. ${ }^{1}-$ BRMEŽ M. $^{2}-$ BENKOVIĆ LAČIĆ, T. ${ }^{3}$ \\ ${ }^{1}$ University of Zagreb, Faculty of Agriculture, Department of Agricultural Zoology \\ Svetošimunska 25, 10000 Zagreb, Croatia (e-mail: djelinic@agr.hr; phone: +385-1-2393-967) \\ ${ }^{2}$ J. J. Strossmayer University of Osijek, Faculty of Agriculture in Osijek, 31000 Osijek, Croatia \\ (e-mail: mbrmez@pfos.hr; phone:+385-31-554-909) \\ ${ }^{3}$ College of Slavonski Brod, Dr. Mile Budaka 1, 35000 Slavonski Brod, Croatia \\ (e-mail: Teuta.Benkovic.Lacic@vusb.hr; phone:+385-35-492-630) \\ *Corresponding author \\ e-mail:djelinic@agr.hr; phone:+385-1-2393-967 \\ (Received $6^{\text {th }}$ Dec 2017; accepted $27^{\text {th }}$ Feb 2018)
}

\begin{abstract}
Vegetable crops, more than other agricultural crops, are exposed to great damages caused by slugs. Current control methods rely on chemical molluscicides that are often ineffective and harmful to non - target organisms, specially Carabids. Parasitic nematode Phasmarhabditis hermaphrodita (Schneider) parasites many slugs and snails and has been formulated as biological molluscicide. In this investigation, effectiveness of $P$. hermaphrodita applied in recommended and half the recommended dose in slug control in greenhouse lettuce and cabbage was evaluated and compared with metaldehyde and methiocarb pellets. Tested mollusicides did not stop feeding of Arion lusitanicus Mabille and did not achieve long term protection from slug damage. The use of standard dose of $P$. hermaphrodita in lettuce and cabbage provided satisfactory protection from slugs to harvest. Half recommended dose of $P$. hermaphrodita showed lower level of protection compared with recommended dose. Repeated applications of half recommended dose of $P$. hermaphrodita could boost molluscicidal effect to the level of the efficacy reached by standard dose, so it could find their place in practice. Effective control of A. lusitanicus using parasitic nematodes provides great opportunity to replace chemical molluscicides in organic production and to reduce their negative side effect to non - target organisms and the environment.
\end{abstract}

Keywords: Arion lusitanicus, cabbage, lettuce, molluscicides, parasitic nematodes

\section{Introduction}

Slugs are serious pests in many crops all over the world (Godan, 1979; Port and Port, 1986; South, 1992) and present one of the most significant threats to sustainable agriculture (Barker, 2002). Their significance as pests is especially evident in vegetable growing. Leafy vegetables such as lettuce and brassica crops are particularly threatened. Slugs feed on plants but they also contaminate it with mucus and faeces (Port and Ester, 2002). In recent years, the slug species Arion lusitanicus Mabille has become a serious pest throughout Central, Northern and Eastern Europe (De Winter, 1989; Fechter and Falkner, 1990; von Proschwitz, 1997; Briner and Frank, 1998; Turner et al., 1998). In Croatia, A. lusitanicus is the most common and the most damaging slug species in vegetable growing (Fischer et al., 1999; Grubišić et al., 2013). Current control methods rely on chemical molluscicides formulated into baited pellets that are often ineffective and can harm non-target organisms. Molluscicides contain metaldehyde or carbamates as active ingredient (Garthwaite and Thomas, 1996; Henderson and Triebskorn, 2002). 
In organic agriculture, the use of slug pellets containing metaldehyde or carbamates is restricted or not allowed. The European Union has baned methiocarb slug pellets since 19 September 2014. The other major slug pellet product metaldehyde has come under pressure after the product has been found in watercourses. A new molluscicide based on iron phosphate has been recently registered in many European countries (Speiser and Kistler, 2002; Rae et al., 2009) and shows promise for slug control, particularly in organic agriculture (Iglesias et al., 2001). Tighter controls over metaldehyde-based slug pellets are likely in high-risk water catchment areas to try and cut pesticide levels in drinking water, which will leave only iron phosphate pellets as an alternative. In the meantime, it was evidented that high doses of iron phosphate increase mortality and reduce surface activity of earthworms (Langan and Shaw, 2006). Therefore, the new solutions for slug control must be investigated. In 1994, the nematode Phasmarhabditis hermaphrodita (Schneider) has been commercialized as a biocontrol agent for slug control (Glen et al., 1996). The nematodes are mass produced in liquid medium in fermenters of up to $20000 \mathrm{~L}$, in monoxenic association with Moraxella osloensis Bøvre \& Henriksen (Rae et al., 2007). This nematode species is used as an inundative biological control agent lethal to many slug species (Wilson et al., 1993; Glen et al., 1996; Speiser et al., 2001; Iglesias and Speiser, 2001; Grewal et al., 2003) although not all of them were killed at a similar rate, what indicated their different sensitivity to the nematode. It was noticed that sensitivity to $P$. hermaphrodita decreases with increasing of body size in large slug specimens of the family Arionidae (Glen et al., 1996; Speiser et al., 2001; Grimm, 2002; Grewal et al., 2003). Also some authors reported that $P$. hermaphrodita causes significant reduction in the plant damage by inhibiting slugs feeding, without causing their death (Glen et al., 1996; Grimm 2002; Rae et al., 2009). Nematode $P$. hermaphrodita has been used to reduce slug damage in a number of agriculture crops (Rae et al., 2007) and has been successfully used in some vegetable crops like cabbage (Grubišić et al., 2003), asparagus (Ester et al., 2003a), Brussels sprouts (Ester et al., 2003b) and Chinese cabbage (Kozłowski et al., 2014). In UK, commercial growers routinely use $P$. hermaphrodita to reduce slug damage in asparagus, lettuce, Brussels sprouts, cabbage and celery (Rae et al., 2007). Biological products based on nematode $P$. hermaphrodita are more expensive than chemical molluscicides and are not available on some markets and to all vegetable producers. Some investigations were aimed in reducing treatment cost through the reducing numbers of nematodes applied, repeated applications of low doses (Ester et al., 2003a,b; Rae et al., 2006, 2009), application of the recommended rate of nematodes in bands or around individual plants (Rae et al., 2009) and immersion of plant roots (Kozłowski et al., 2014). A significant fact like is that $P$. hermaphrodita may survive approximately six weeks in soil (Kozlowska et al., 2014) or up to 99 days (Vernavá et al., 2004) indicates that it is not necessary to apply the product multiple times, what could bring significant reduction in costs of protecting plants by use of $P$. hermaphrodita based products. The aim of this study was to investigate the possibility of reducing the recommended dose of $P$. hermaphrodita, by using it in combination with metaldehyde and in half recommended dose, in control of slug species A. lusitanicus in cabbage and lettuce crops. Also the aim was to check the efficiency of chemical molluscicides in control of A. lusitanicus, considering the dissatisfaction of producers with their effectiveness in practice and their limited use in organic production. 


\section{Materials and methods}

Greenhouse experiment was performed on a commercial lettuce farm at Petina near Zagreb Croatia from October 6 to November 9 2009. Investigation in cabbage was conducted in greenhouse at Čehi near Zagreb Croatia from March 30 to May 5 2010. In both locations prevail alluvial carbonate loamy soil. Mean daily temperature evidented at Petina, while conducting experiment in lettuce, was $9.3^{\circ} \mathrm{C}$ and the mean soil temperature at $10 \mathrm{~cm}$ depth was $11.8^{\circ} \mathrm{C}$. Mean daily temperature evidented at Čehi was $13.4{ }^{\circ} \mathrm{C}$, while the mean soil temperature at $10 \mathrm{~cm}$ depth was also $13.4{ }^{\circ} \mathrm{C}$. Lettuce (variety Lollo Bionda) and cabbage (variety Jetma $\mathrm{F}_{1}$ ) transplants were planted in rows $30 \mathrm{~cm}$ apart. The slug species determined in greenhouse lettuce and cabbage was $A$. lusitanicus (Fig. 1). There were six treatments: (1) untreated control; (2) metaldehyde pellets (5\% a.i., recommended rate); (3) methiocarb pellets (4\% a.i., recommended rate); (4) $P$. hermaphrodita (30 nematodes per $\mathrm{cm}^{2}$, recommended rate); (5) $P$. hermaphrodita (15 nematodes per $\mathrm{cm}^{2}$, half the recommended rate) and (6) metaldehyde pellets (half the recommended rate) $+P$. hermaphrodita (half the recommended rate). There were four replicates $(2 \times 2 \mathrm{~m})$ of each treatment arranged in a randomised block design. In experiment, commercial formulation of $P$. hermaphrodita known as Phasmarhabditis - System (Biobest N.V., Belgium) was used. The nematodes were stirred in watering can full of water and applied over the soil surface using a watering can fitted with a rose (Fig. 2. and Fig. 3). Pellets of molluscicides were broadcasted by hand. Slug damage in lettuce experiment (Table 1) was assessed visually by estimating the percentage of leaf area eaten by slugs 2, 7, 13, 19 and 33 days after treatment and in cabbage experiment $7,10,17,23,31$ and 38 days after treatment (Table 2). All data were subjected to ANOVA and Duncan's New MRT $(\mathrm{P}=.05)$. Different intervals in estimating the slug damage were due to different speed of development of the lettuce and cabbage plants in different periods of the year. Also lettuce transplants were more sensitive and gentle so estimating started earlier. In cabbage, estimating lasted longer because of longer period since picking time.

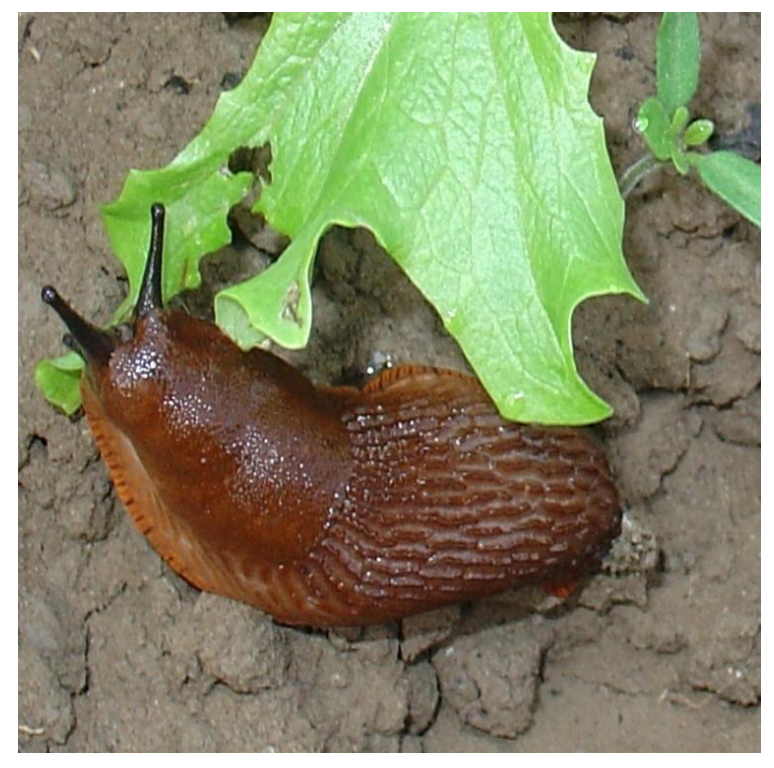

Figure 1. Slug species Arion lusitanicus in lettuce

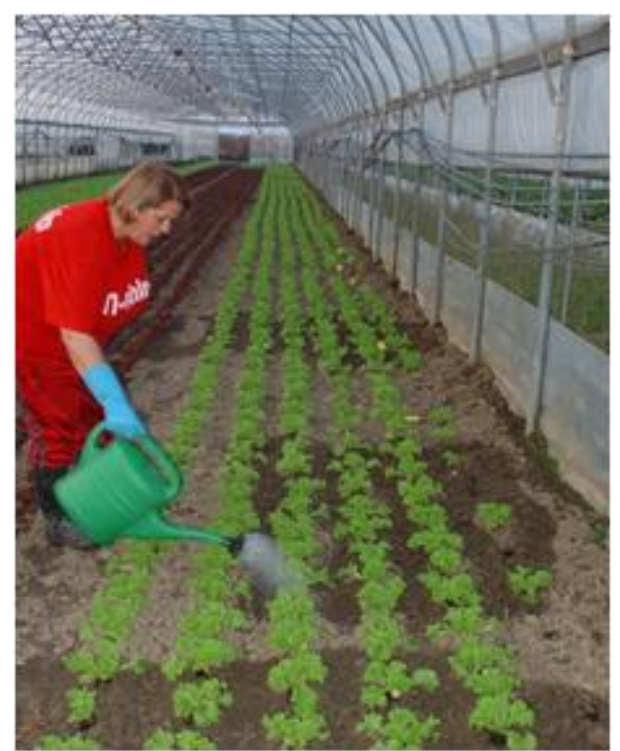

Figure 2. Application of $P$. hermaphrodita in lettuce 


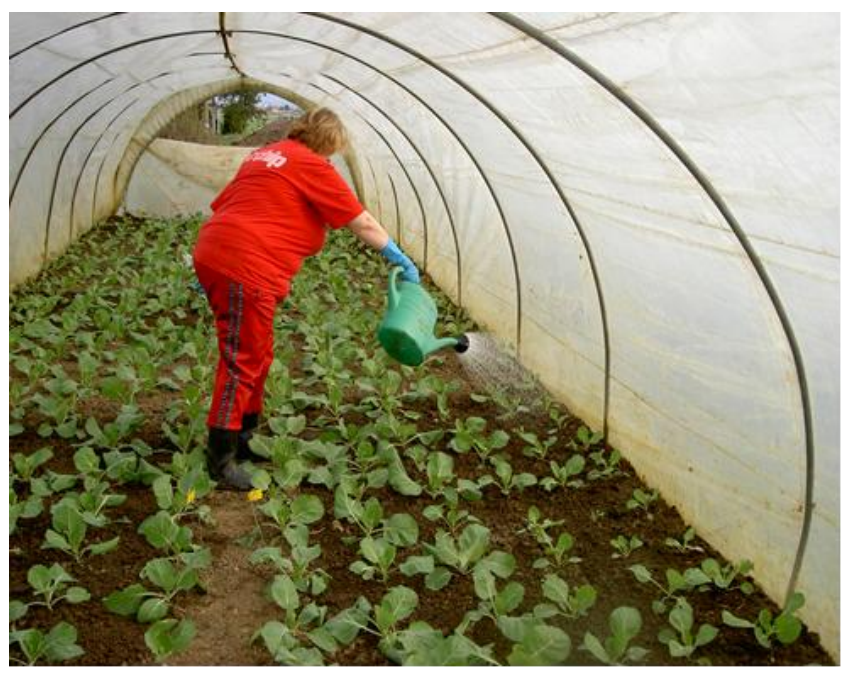

Figure 3. Application of P. hermaphrodita in cabbage

\section{Results}

In greenhouse experiment conducted in lettuce for 33 days (Table 1), from the second day onwards, damages evidented on all treatments were significantly less than on the untreated control, indicated good slug control. Up to day 7 all treatments were equally successful. On day 13 better protection than on the other treatments was provided by metaldehyde pellets applied in recomended dose. Methiocarb pellets were less effective than metaldehyde, what was also confirmed on the last day of assessment. On day 13 recommended dose of $P$. hermaphrodita differed from the other treatments, provided the lowest level of slug control, but from day 19 to day 33 reduction in slug feeding was noticed. On day 33 the level of protection provided by recommended dose of $P$. hermaphrodita was higher than of other treatments. Since day 19 until the end of the experiment, damages on half recommended doses of $P$. hermaphrodita have been in progress.

Table 1. Slug damage (in \%) after chemical and biological molluscicides use in lettuce greenhouse experiment

\begin{tabular}{|c|c|c|c|c|c|c|}
\hline \multirow[b]{2}{*}{$\begin{array}{l}\text { No. of } \\
\text { treatment }\end{array}$} & \multirow[b]{2}{*}{ Treatment } & \multicolumn{5}{|c|}{ Days after treatment } \\
\hline & & 2 & 7 & 13 & 19 & 33 \\
\hline 1 & Untreated & $65.25 \mathrm{a}^{*}$ & $47.00 \mathrm{a}$ & $50.75 \mathrm{a}$ & $64.75 \mathrm{a}$ & $43.00 \mathrm{a}$ \\
\hline 2 & Metaldehyde & $2.00 \mathrm{~b}$ & $1.75 b$ & $4.75 c$ & $4.50 \mathrm{~b}$ & $4.00 \mathrm{bc}$ \\
\hline 3 & $\begin{array}{l}\text { P.hermaphrodita } 1 / 2 \\
\text { dose }\end{array}$ & $3.75 \mathrm{~b}$ & $2.25 \mathrm{~b}$ & $10.00 \mathrm{bc}$ & $3.25 \mathrm{~b}$ & $4.00 \mathrm{bc}$ \\
\hline 4 & $\begin{array}{l}\text { P.hermaphrodita } 1 / 2 \\
\text { dose }+1 / 2 \text { dose } \\
\text { metaldehyde }\end{array}$ & $1.5 \mathrm{~b}$ & $2.00 \mathrm{~b}$ & $6.25 b c$ & $3.00 \mathrm{~b}$ & $4.00 \mathrm{bc}$ \\
\hline 5 & $\begin{array}{l}\text { P.hermaphrodita } \\
\text { recommended dose }\end{array}$ & $3.25 \mathrm{~b}$ & $1.75 b$ & $12.25 b$ & $4.50 \mathrm{~b}$ & $3.50 \mathrm{c}$ \\
\hline 6 & Methiocarb & $0.3 \mathrm{~b}$ & $2.00 \mathrm{~b}$ & $7.25 b c$ & $6.00 \mathrm{~b}$ & $5.00 \mathrm{~b}$ \\
\hline & LSD P $=5 \%$ & 5.484 & 3.677 & 5.836 & 5.164 & 1.263 \\
\hline
\end{tabular}

*means followed by same letter are not significantly different according to Duncan's multiple range test $(\mathrm{P}=.05)$ 
In the experiment in cabbage (Table 2), all treatments were significantly different from the control, and of equal efficacy in slug control, from the first week to day 23 after treatment. On day 23 metaldehyde showed significantly lower efficacy than other treatments. Towards the end of the experiment (day 38), leaf damages started to increase and the best efficacy in slug control was obtained by the recommended dose of $P$. hermaphrodita. Treatments 2, 3 and 4 did not differ significantly. Methiocarb was significantly less effective than recommended dose of $P$. hermaphrodita and, according to estimated slug damage, though not statistically, less effective than metaldehyde.

Mean percentage of slug damage in lettuce experiment evidented on all treatments was $4,1 \%$ and in cabbage experiment was $17,5 \%$. Considering assessed $43 \%$ damage on control plots in lettuce and $43,15 \%$ in cabbage, all treatments significantly reduced slug damage, although they did not stop slug feeding.

Table 2. Slug damage (in \%) after chemical and biological molluscicides use in cabbage greenhouse experiment

\begin{tabular}{|c|c|c|c|c|c|c|c|}
\hline \multirow[b]{2}{*}{$\begin{array}{l}\text { No. of } \\
\text { treatment }\end{array}$} & \multirow[b]{2}{*}{ Treatment } & \multicolumn{5}{|c|}{ Days after treatment } & \multirow[b]{2}{*}{38} \\
\hline & & 7 & 10 & 17 & 23 & 31 & \\
\hline 1 & Untreated & $27,89 \mathrm{a}$ & $48,2 \mathrm{a}$ & $50,52 \mathrm{a}$ & $20,97 a$ & $16,52 \mathrm{a}$ & $43,15 a$ \\
\hline 2 & Metaldehyde & $0,5 b$ & $2,25 \mathrm{~b}$ & $1,92 b$ & $19,24 \mathrm{a}$ & $12,77 \mathrm{ab}$ & $15,44 \mathrm{bc}$ \\
\hline 3 & $\begin{array}{l}\text { P.hermaphrodita } \\
1 / 2 \text { dose }\end{array}$ & $1,71 b$ & $3,36 b$ & $3,23 b$ & $3,39 b$ & $4,71 \mathrm{c}$ & $20,81 b c$ \\
\hline 4 & $\begin{array}{l}\text { P.hermaphrodita } \\
1 / 2 \text { dose }+1 / 2 \text { dose } \\
\text { metaldehyde }\end{array}$ & $1,22 b$ & $2,22 b$ & $2,08 \mathrm{~b}$ & $9,04 b$ & $8,52 \mathrm{bc}$ & $18,52 b c$ \\
\hline 5 & $\begin{array}{l}\text { P.hermaphrodita } \\
\text { recommended dose }\end{array}$ & $0,68 b$ & $1,75 b$ & $2,17 \mathrm{~b}$ & $4,36 b$ & $3,78 \mathrm{c}$ & $7,22 \mathrm{c}$ \\
\hline 6 & Methiocarb & $3,11 \mathrm{~b}$ & $2,67 b$ & $2,33 b$ & $9,86 \mathrm{~b}$ & $6,99 \mathrm{c}$ & $25,37 b$ \\
\hline & $\mathrm{LSD} P=5 \%$ & 3,689 & 5,513 & 5,008 & 8,203 & 5,125 & 14,464 \\
\hline
\end{tabular}

*means followed by same letter are not significantly different according to Duncan's multiple range test $(\mathrm{P}=.05)$

\section{Discussion}

Slug species A. lusitanicus is very hard to control, what has been observed by many vegetable producers (Grubišić et al., 2013). In the experiments in lettuce (lasting for 33 days) and in cabbage (lasting for 38 days) slug feeding was evidented on all treatments and on every assessment day. In experiment conducted under laboratory conditions in Croatia (Grubišić et al., 2013) adult specimens of $A$. lusitanicus infected by $P$. hermaphrodita died within 3 to 30 days. Death of infected slugs within 4 to 20 days, depending on temperature and abundances of the nematodes, have also been reported by Glen et al. (2000) and Grewal et al. (2001, 2003). At the treatments metaldehyde and methiocarb slugs were dying in the period of 9 to 24 days (Grubišić et al., 2013). Food consumption was reduced on both chemical (methiocarb and metaldehyde) and biological ( $P$. hermaphrodita) treatments but the most of adult specimens of $A$. lusitanicus continued to feed with different extent until death (Grubišić et al., 2013) what could explain slug damages evidented in lettuce and cabbage by the end of field experiments. Some previous investigations (Speiser et al., 2001; Grimm, 2002) also pointed at the negative effect of slug size on the efficacy of $P$. hermaphrodita as the reason of unsatisfactory pest control. 
Mean percentage of slug damage in lettuce experiment evidented on treatments 2, 3, 4, 5 and 6 the last day of assessment was $4,1 \%$, so all treatments significantly reduced slug damage in relation to untreated control. Considering slug pest species $A$. lusitanicus and assessed $43 \%$ slug damage on control plots, even higher damages were expected on tested treatments. On day 13 and 19, mean percentage of slug damage on treatment with recommended rate of $P$. hermaphrodita was higher than on half the recommended rate (treatments 5 and 6), though not statistically. Considering results that $D$. reticulatum and $A$. ater actively avoid areas of soil where $P$. hermaphrodita is present at densities of 38 and $120 \mathrm{~cm}^{-2}$ (Wilson et al., 1999), and a density of $38 \mathrm{~cm}^{-2}$ is close to the recommended rate of $P$. hermaphrodita $\left(30 \mathrm{~cm}^{-2}\right)$, it is possible that at the plots where recommended rate of nematodes were applied, slugs were more of the time at the soil surface thus causing more damage to lettuce. Additionally, larger specimens noticed in lettuce crop usually stay on the soil surface (Frank, 1998) so it could be difficult for nematodes, which were applied on and live in soil to infect them. Many trials (Ester et al., 2003a,b; Grewal et al., 2001; Rae et al., 2009) have shown that repeated applications of low rate of $P$. hermaphrodita provided a significant reduction to slug damage, even as well as metaldehyde pellets. By the end of lettuce experiment (on day 33) equable results were evidented with only one application of half recommended rate of $P$. hermaphrodita and metaldehyde. On day 33 recommended rate of $P$. hermaphrodita expressed better control of slugs in lettuce than the other treatments and significantly better than methiocarb. Treatment with $P$. hermaphrodita was also superior to methiocarb treatment in several experiments reported by Wilson et al. (1994a,b) and Glen et al. (1996). Repeated application of half recommended rate of $P$. hermaphrodita could boost molluscicidal effect to the level of the efficacy reached by recommended rate of $P$. hermaphrodita at the end of the experiment.

In cabbage experiment recommended rate of $P$. hermaphrodita protected plants from slug damage effectively to day 38 . In previous investigations in cabbage crop in Croatia (Grubišić et al., 2003) recommended rate of $P$. hermaphrodita also provided satisfactory protection for 30 days after application, until picking time. Up to day 31 in cabbage experiment, half the recommended dose of $P$. hermaphrodita showed statistically equable results as standard dose of $P$. hermaphrodita, while on day 38 damages on treatment with half recommended dose of $P$. hermaphrodita increased. These results indicate that three to four weeks, after the first application of half the recommended rate, it should be applied again if vegetable is grown for a such a long period. Considering the results obtained by Ester et al. (2003a,b), Grewal et al. (2001), Rae et al. (2009) and the results achieved at the end of both experiments in lettuce and cabbage, the need of repeated application of half the recommended $P$. hermaphrodita rate, about three to four weeks after the first application, in order to maintain the level of efficacy to harvest, should be considered.Vernaváet al. (2004) found that nematodes were still in the soil 99 days after application of biological product based on $P$. hermaphrodita, but the height of nematodes population could be questionable.

\section{Conclusion}

All treatments, chemical (based on metaldehyde and methiocarb) and biological (based on parasitic nematode $P$. hermaphrodita), in both experiments significantly reduced slug damage in relation to untreated control. According to estimated slug damage on the last day of assessment in both experiments, though not always 
statistically, recommended dose of $P$. hermaphrodita expressed better control of slugs than the other treatments. In practice, in some cases, higher yields or products of higer quality, means a lot to the producers, even the results were not statistically approved. Based on the results achieved in lettuce and cabbage experiment, it was noticed that the height of nematodes population could determine the effectiveness of nematodes in slug control, so re-application of half recommended doses of $P$. hermaphrodita, about three to four weeks after the first application, could be justified. This approach should be tested in further investigations. Re-treatments of chemical mollusicides, due to loss of efficacy, are not allowed because of the waiting period ( 21 days) and the proximity of harvest. Biological control of slugs using $P$. hermaphrodita should be tested in other vegetable crops in greenhouses but also in the field. The achieved results would be of great importance especially in organic vegetable growing and under the circumstances of the fewer number of limacides on the market.

Acknowledgements. This work was funded by a VIP research project VIII-5-20/08 of Ministry of Agriculture, Fisheries and Rural Development and Ura-dva d.o.o. We thank Leko M d.o.o. for import of Phasmarhabditis - System (Biobest N.V., Belgium).

\section{REFERENCES}

[1] Barker, G.M. (2002): Molluscs as Crop Pests. - CABI Publishing. Wallingford, Oxon OX 10 8DE, UK, 468 pp.

[2] Briner, T., Frank T. (1998): Egg laying activity of the slug Arion lusitanicus Mabille in Switzerland. - Journal of Conchology 36: 9-15.

[3] De Winter, A.J. (1989): Arion lusitanicus Mabille in Nederland (Gastropoda: Pulmonata: Arionidae). - Basteria 53: 49-51.

[4] Ester, A., Rozen, K. van, Molendijk, L.P.G. (2003a): Field experiments using rhabditid nematode Phasmarhabditis hermaphrodita or salt as control measures against slugs in green asparagus. - Crop Protection 22: 689-695.

[5] Ester, A., Huiting, H.F., Molendijk, L.P.G., Vlaswinkel, M.E.T. (2003b): The rhabditid nematode Phasmarhabditis hermaphrodita Schneider as a potential biological control agent to control field slugs Deroceras reticulatum (Müller) in Brussel sprouts. - In: Slugs and Snails: Agricultural, Veterinary and Environmental Perspectives, BCPC Symposium Proceedings No 80. British Crop Protection Council, Alton, Hants, UK: 313-318.

[6] Fischer, W., Reischütz, A., Reischütz, P.L. (1999): Die Spanische Wegschnecke in Kroatien. - Club Conchylia Informationen 31 (3/4): 15-17.

[7] Frank, T. (1998): The role of different slug species in damage to oilseed rape bordering on sown wildflower strips. - Annals of applied Biology 133: 483-493.

[8] Fechter, R., Falkner, G. (1990): Weichtiere. - Steinbachs Naturführer, Mosaik Verlag, München, Germany, 287 p.p.

[9] Glen, D.M., Wilson, M.J., Hughes, L., Cargeeg Hajjar, A. (1996): Exploring and exploting the potential of the Rhabditidae nematode Phasmarhabditis hermaphrodita as a biocontrol agent for slugs. - In: Henderson, I.F. (ed): Slug \& Snail Pests in Agriculture. British Crop Protection Council, Farnham, UK: 271-280.

[10] Glen, D.M., Wilson, M.J., Brain, P., Stroud, G. (2000): Feeding activity and survival of slugs, Deroceras reticulatum, exposed to the rhabditid nematode, Phasmarhabditis hermaphrodita: a model of dose response. - Biological Control 17: 73-81.

[11] Garthwaite, D.G., Thomas, M.R. (1996): The usage of molluscicides in agriculture and horticulture in Great Britain over the last 30 years. - In: Henderson, I.F. (ed): Slug \& Snail Pests in Agriculture. British Crop Protection Council, Farnham, UK: 39-46. 
[12] Godan, D. (1979): Schadschnecken und ihre Bekämpfung. - Ulmer, Stuttgart, Germany, 467 p.p.

[13] Grewal, P.S., Grewal, S.K., Taylor, R.A., Hammond, R.B. (2001): Application of molluscicidal nematodes to slug shelters: a novel approach to economic biological control of slugs. - Biological Control 22: 72-80.

[14] Grewal, S.K., Grewal, P.S., Hammond, R.B. (2003): Susceptibility of north American native and non-native slugs (Mollusca: Gastropoda) to Phasmarhabditis hermaphrodita (Nematoda: Rhabditidae). - Biocontrol Science and Technology 13: 119-125.

[15] Grimm, B. (2002): Effect of the nematode Phasmarhabditis hermaphrodita on young stages of the pest slug Arion lusitanicus. - Journal of Molluscan Studies 68: 25-28.

[16] Grubišić, D., Oštrec, Lj., Dušak, I. (2003): Biological control of slugs in vegetable crops in Croatia. - In: Slugs and Snails: Agricultural, Veterinary and Environmental Perspectives, BCPC Symposium Proceedings No 80. British Crop Protection Council, Alton, Hants, UK: 115-120.

[17] Grubišić, D., Hamel, T., Gotlin Čuljak, T., Loparić, A., Brmež M. (2013): Feeding activity and survival of slug Arion lusitanicus (Gastropoda: Arionidae) exposed to the rhabditid nematode, Phasmarhabditis hermaphrodita (Nematoda: Rhabditidae). - Insect pathogens and entomoparasitic nematodes IOBC - WPRS Bulletin 90: 297-300.

[18] Grubišić, D., Hamel, T., Gotlin Čuljak, T., Loparić, A., Brmež, M. (2013): Feeding activity and survival of slug Arion lusitanicus (Gastropoda: Arionidae) exposed to the rhabditid nematode, Phasmarhabditis hermaphrodita (Nematoda: Rhabditidae). - IOBCWPRS Bulletin, Proceedings of the Meeting "Biological control - its unique role in organic and integrated production" / Jehle, Johannes A., Bažok, Renata, Crickmore, Neil, Lopez-Ferber, Miguel, Glazer, Itamar, Quesada-Moraga, Enrique, Traugott, Michael. (ur.). Darmstadt : IOBC , 2013. 297-300 (ISBN: 978-92-9067-268-5).

[19] Henderson, I.F., Triebskorn, R. (2002): Chemical control of terrestrial gastropods. - In: Barker, G.M. (ed.) Molluscs as Crop Pests. CABI Publishing, Wallingford, Oxon OX 10 8DE, UK: 1-31.

[20] Iglesias, J., Castillejo, J., Castro, R. (2001): Mini - plot field experiments on slug control using biological and chemical control agents. - Annals of Applied Biology 139: 285-292.

[21] Iglesias, J., Speiser, B. (2001): Consumption rate and susceptibility to parasitic nematodes and chemical molluscicides of the pest slug Arion hortensis s.s. and Arion distinctus. - Journal of Pesticide Science 74: 159-166.

[22] Kozlowska, M., Jaskulska, M., Łacka, A., Kozlowski, R.J. (2014): Analysis of studies of the effectiveness of a biological method of protection for organic crops. - Biometrical letters, 51 (1): 45-56.

[23] Kozłowski, J., Jaskulska, M., Kozłowska, M. (2014): Evaluation of effectiveness of iron phosphate and parasitic nematode Phasmarhabditis hermaphrodita in reducing plant damage caused by the slug Arion vulgaris Moquin - Tandon, 1885. - Folia Malacologica 22 (4): 293-300.

[24] Langan, M.A., Shaw, E.M. (2006): Response of the earthworm Lumbricus terrestris (L.) to iron phosphate and metaldehyde slug pellet formulations. - Applied Soil Ecology 34: 184-189.

[25] Port, C.M., Port, G.R. (1986): The biology and behaviour of slugs in relation to crop damage and control. - Agricultural Zoology Reviews 1: 255-299.

[26] Port, G., Ester, A. (2002): Gastropods as Pests in Vegetable and Ornamental Crops in Western Europe. - In: Barker, G.M. (ed.) Molluscs as Crop Pests. CABI Publishing, Wallingford, Oxon OX 10 8DE, UK: 337-351.

[27] von Proschwitz, T. (1997): Arion lusitanicus Mabille and A. rufus (L.) in Sweden: A comparison of occurence, spread and naturalization of two alien slug species. - Heldia 4: 137-138. 
[28] Rae, R.G., Robertson, J.F., Wilson, M.J. (2006): The chemotactic response of Phasmarhabditis hermaphrodita (Nematoda: Rhabditidae) to cues of Deroceras reticulatum. - Nematology 8: 197-200.

[29] Rae, R., Verdun, C., Grewal, P.S., Robertson, J.F., Wilson, M. (2007): Biological control of terrestrial molluscs using Phasmarhabditis hermaphrodita - progress and prospects. Pest Management Science 63: 1153-1164.

[30] Rae, R.G., Robertson, J.F., Wilson, M.J. (2009): Optimization of biological (Phasmarhabditis hermaphrodita) and chemical (iron phosphate and metaldehyde) slug control. - Crop Protection 28: 765-773.

[31] South, A. (1992): Terrestrial Slugs. Biology, Ecology, Control. - Chapman \& Hall, London, UK, 428 p.p.

[32] Speiser, B., Zaller, J.G., Newdecker, A. (2001): Size-specific susceptibility of the pest slugs Deroceras reticulatum and Arion lusitanicus to the nematode biocontrol agent Phasmarhabditis hermaphrodita. - Biocontrol 46: 311-320.

[33] Speiser, B., Kistler, C. (2002): Field test with a molluscicide containing iron phosphate. Crop Protection 21: 389-394.

[34] Turner, H., Kuiper, J.G.J., Thew, N., Bernasconi, R., Rüetschi, J., Wüthrich, M., Gosteli, M. (1998): Atlas der Molluscen der Schweiz und Liechtensteins. - Fauna Helvetica, CSCF, Neuchâtel, Switzerland, 527 p.p.

[35] Vernavá, M.N., Phillps-Aalten, P.M., Highes, L.A., Rowcliffe, H., Wiltshire, C.W., Glen, D.M. (2004): Influences of proceding cover crops on slug damage and biological control using Phasmarhabditis hermaphrodita. - Annals of Applied Biology 145: 279-284.

[36] Wilson, M.J., Glen, D.M., George, S.K. (1993): The rhabditid nematode Phasmarhabditis hermaphrodita as a potential biological control agent for slugs. - Biocontrol Science and Technology 3: 503-511.

[37] Wilson, M.J., Glen, D.M., George, S.K., Pearce, J.D., Wiltshire, C.W. (1994a): Biological control of slugs in winter wheat using the rhabditid nematode Phasmarhabditis hermaphrodita. - Annals of Applied Biology 125: 377-390.

[38] Wilson, M.J., Glen, D.M., Wiltshire, C.W., George, S.K. (1994b): Mini-plot field experiments using rhabditid nematode Phasmarhabditis hermaphrodita for biocontrol of slugs. - Biocontrol Science and Technology 4: 103-113.

[39] Wilson, M.J., Hughes, L.A., Jefferies, D., Glen, D. M. (1999): Slugs (Deroceras reticulatum and Arion ater agg.) avoid soil treated with the rhabditid nematode Phasmarhabditis hermaphrodita. - Biological Control 16: 170-176. 